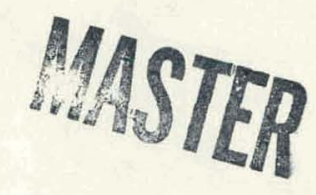

\title{
EQUIPMIANT FOR COLLECTING SLUDGE SAMPLES FROM SAVANNAH RIVER PLANT WASTE TANKS
}

by

Burgess M. Allen, Jr.

Savannah River Laboratory

E. I. du Pont de Nemours \& Co. (Inc.)

Aiken, South Carolina 29801

A proposed paper for publication and for presentation at the American Nuclear Society Winter Meeting, November 11-16, 1979, in San Francisco, CA.

This paper was prepared in connection with work under Contract No. DE-AC09-76SR00001 with the U.S. Department of Energy. By acceptance of this paper, the publisher and/or recipient acknowledges es the U.S. Government's right to retain a nonexclusive, royaltyfree license in and to any copyright covering this paper, along with the right to reproduce and to authorize others to reproduce all or part of the copyrighted paper. 


\section{DISCLAIMER}

This report was prepared as an account of work sponsored by an agency of the United States Government. Neither the United States Government nor any agency Thereof, nor any of their employees, makes any warranty, express or implied, or assumes any legal liability or responsibility for the accuracy, completeness, or usefulness of any information, apparatus, product, or process disclosed, or represents that its use would not infringe privately owned rights. Reference herein to any specific commercial product, process, or service by trade name, trademark, manufacturer, or otherwise does not necessarily constitute or imply its endorsement, recommendation, or favoring by the United States Government or any agency thereof. The views and opinions of authors expressed herein do not necessarily state or reflect those of the United States Government or any agency thereof. 


\section{DISCLAIMER}

Portions of this document may be illegible in electronic image products. Images are produced from the best available original document. 
RQUIPURAT POR COLLECTING SLUDGE SAMPLES

PROM SAVANTAH RIVER PLANT WASTE TANRS*

ABSTRACT

A sampler was developed to take 25-L samples of sludge from Savannah River Plant waste tanks. The cylindrical sample vessel has a retractable nose section. Sludge enters an annular space at the nose section as the sampler 18 forced through the sludge layer with rigid drive pipes. Two samples have been taken and transported in a special cask to a waste processing research facility at the Savannah River Laboratory.

* The information contained in this article was developed during the course of work under Contract No. DE-AC09-76SR00001 with the U.S. Department of Energy. 


\section{INTRODOCTION}

The Savannah River Laboratory (SRL) is developing ways to solidify high-level radioactive waste from separation processes of the Savannah River Plant (SRP). The waste is stored in $4 \times 10^{6} \mathrm{~L}$ tanks. Gelatinous sludge occupying about $10 \%$ of the total waste volume settles out from alkaline waste solutions. The sludge is hydrous oxides of various metal lons with up to .22 curies of alpha activity and 75 curies of beta and gamma activity per liter.

Equipment was developed to collect this sludge for waste processing studies. This equipment has the capacity to gather a 25-L sample from a desired point in the sludge layer. The sample is transported to the SRL Waste Processing Development Facility in a special cask.

Previous waste sludge for smaller scale research studies was obtained in a 3-L sampler. The 3-L sampler was lowered into the waste tanks by a cable. The sampler could not be positioned in the sludge layer, and generally only samples from the top of the sludge layer were obtalned.

In 1977 , a larger scale waste vitrification development program was begun. In this program, the sludge collected is washed to remove soluble salts, calcined, mixed with frit material, and fed into a $3200-g$ capacity melter. The new sampler was developed to supply the larger quantities of waste sludge required for this program. The 25-L sampler is the largest optimum size compatible with the waste tank sample port riser opening and the material handling space and 
equipment in the processing facility. Unlike the 3-L sampler, the large 25-L sampler has detachable drive pipes to allow positive retrleval of samples from precise levels.

\section{SLUDGE SAMPLING EQUIPMENT}

The sludge sampling equipment (Figure 1) consists of a sludge sampler, drive pipes, waste tank riser shields, and a transport cask.

\section{Sludge Sampler}

The 25-L sludge sampler (Figure 2) is cylindrical, $1.5 \mathrm{~m}$ long, with a $25.4-\mathrm{cm}$-diameter chamber $95.3 \mathrm{~cm}$ in length. Detachable drive pipe sections are connected to a 9-cm-diameter p1pe stem at the upper end of the $95-\mathrm{kg}$ sampler. The sampler is constructed of 304-L stainless steel.

The nose cone of the sampler is retracted for opening and extended for closing by a double-acting, double-ended hydraulic cylinder installed inside the sampler. A closing force of $735 \mathrm{~kg}$ on an o-ring seal between the nose cone and the sampler body ensures a leaktight container. An annular opening is formed between the nose cone and the outside of the sampler when the nose cone is retracted. Sludge flows into the sampler through the annulus when the sampler is pushed through the sludge. The upper shaft of the hydraulic cylinder is attached to a vent piston. The vent allows air or supernate to pass through the sampler when the sampler is in the open position. The vent is sealed when the sampler is in the closed position. 
A spray ring is mounted internally on the back plate of the sampler. A quick disconnect is attached to the outside of the sampler for connection of a high-pressure washer. The spray ring aids in cleaning the inside of the sampler. The sampler was designed with minimum sludge entrapment areas to make cleaning easier. The sampler can be disassembled remotely for decontamination and maintenance. The pipe stem sections and the nose cone section are gasketed and bolted to the main sampler body. A gasketed and bolted hatch is provided on the side of the sampler for access to the hydraulic cylinder.

Quick disconnects are provided at the pipe stem section for two hydraulic service tubes to the operating cylinder. The quick disconnects are dissimilar to prevent mismatching the hydraulic 1ines. Both quick disconnects have internal check valves. When the fitting is disconnected, hydraulic pressure will remain on the operating cylinder and lock it in place.

The sampler is a relatively simple mechanism built to withstand the driving force exerted upon it by the drive pipe. The weight of the sampler and drive pipe is approximately $320 \mathrm{~kg}$. The sampler head is designed to withstand a loading of $900 \mathrm{~kg}$.

\section{Drive PIpe}

Drive pipe sections are rigidly attached to the sampler pipe stem. The detachable pipes are 2.9 meters $10 n g$ and are made of 3-inch sch 80 SST pipe. Drive pipes and joints are designed with 
a smooth exterior surface for minimal sludge entrapment. The pipe joints (Figure 3) are connected by a single lock bolt. The joints are sealed by O-rings to prevent seepage of sludge and supernate into the joint. The seals minimize the bulldup of contamination and prevent grit from burring the pipe joints. The assembled drive pipes can withstand a compression load of $900 \mathrm{~kg}$. The drive pipes provide precise placement of the sampler and additional weight to force the sampler through the sludge.

\section{Riser Shleld}

The sampler enters and exits the waste tank through a twopiece. riser shield (Figure 4), equivalent to $8.0 \mathrm{~cm}$ of lead. The shield protects operating personnel from high radiation exposure.

The lower shield, 1.2-m-square by 8.0-cm-thick, sits directly over the waste tank riser. A 34-cm-diameter hole in the center allows entry of the sludge sampler. A spray ring is attached to the bottom for washing the drive pipes and sampler as they are removed from the tank.

The upper shield, 43-cm-square by $8.0-\mathrm{cm}$ thick, slides over the hole in the lower shield. Teflon (Du Pont) strips and guide angles facilitate movement of the upper shield.

A pipe welded in the center of the upper shield allows clearance of the sampler pipe stem and drive pipes. A 1-1n.-wide slot from one edge to the center of the upper shield provides cable clearance for positioning the upper shield while the sampler is suspended in the tank. 


\section{Sludge Transport Cask}

The sampler is transported between the waste tanks and the High Level Caves in a cask. The cask (Figure 5) is a modifled, SRL 8-ton cask which has a bottom opening.

For loading, the cask is positioned directly over the waste tank riser shield, and the sampler is raised into the cask cavity. A 12-volt battery-powered winch mounted on top of the cask raises or lowers the sampler. The winch has a handle to manually raise or lower the sampler in case of motor fallure.

A secondary container is used inside the cask to catch sludge leaks. The container's top has three spring clips that fasten over the top of the sampler to hold the container in place. The secondary contalner is clipped onto the sampler after it has been winched into the cask above the riser shielding (F1gure 6).

\section{OPERATIOR}

A contalnment hut 18 bullt over the waste tank sampling area, and the riser plug is removed. The cover shielding is set directly over the riser. A motor crane is used to postlion the open-bottom sludge cask over the riser. With the cask winch, Llie samplcr is lowered and positioned below the lower shield in the riser. The upper shield is slid into position over the lower shield. The slot in the upper shield allows passage of the winch cable. The sampler is raised so that its pipe stem extends through the sleeve in the upper shield. A clamp (Figure 7) is installed on the pipe stem and the sampler lowered so that the sampler is supported by the clamp 
on the riser shield. Slack cable is run off the cask winch and the cask moved to the side, disconnected from the sampler, and set aside.

The motor crane is used to position drive pipe sections for connection to the sampler. The sampler is lowered to the desired sludge depth by addition of drive pipe sections. The sampler is hydraulically opened and then closed to trap a sludge sample.

Quick disconnects allow remote disconnection of hydraulic lines. Hydraulic fluld trapped in the sampler-operating cylinder ensures that the sampler will remain closed.

The sampler is removed from the waste tank and put into the cask by reversing the installing procedure. The spray ring is used to wash the sampler and drive pipe sections as they are removed from the waste tank. The drive pipes are drawn in plastic bags as they are removed for decontamination at a later time. The secondary container is installed while the sampler is suspended Inside the cask over the riser. The secondary container is placed over a support fixture directly under the cask. The cask is lowered so that the secondary container flts luto the annulus formed between the sampler and the cask cavity. Thiee spring clips at the top of the secondary container engage with the tup edge of the sampler body. The cask bottom is attached and the cask ohipped to the processing facility.

At the processing facility, the sampler is lowered into the cell through a roof plug. The cask cable is disconnected, and the 
sampler is connected to an in-cell bridge crane. The sampler is moved to the sample unloading cell where unloading operations are performed remotely. Hydraulic lines are attached to the sampler, and its nose cone is retracted. A high-pressure water line is attached to the sampler's internal spray ring. After the sampler 1s sprayed internally, the sampler is laid on 1ts side, and highpressure water is directed into the nose cone to further clean the sampler. It takes 70 liters of water to wash the sampler. The sampler exterior is wiped down remotely and the sampler Is inspected, leak checked, and loaded back into the cask.

\section{SAMPLE EQUIPMEAT PERPORHANGB}

The sample equipment has been successful for two sample operations. The tanks sampled had sludge depths of 6 and 10 feet. The sampler was opened 4 feet above the bottom of the tank and lowered to the bottom before belng closed. Even though both samples were thick and viscous sludge, full 25-L samples were taken.

The total maximum radiation exposure to personnel was 195 mrems shared by six operators during a sampling operation. There have been no signs of sample leakage, and no repair or modifications to equipment have been necessary. 


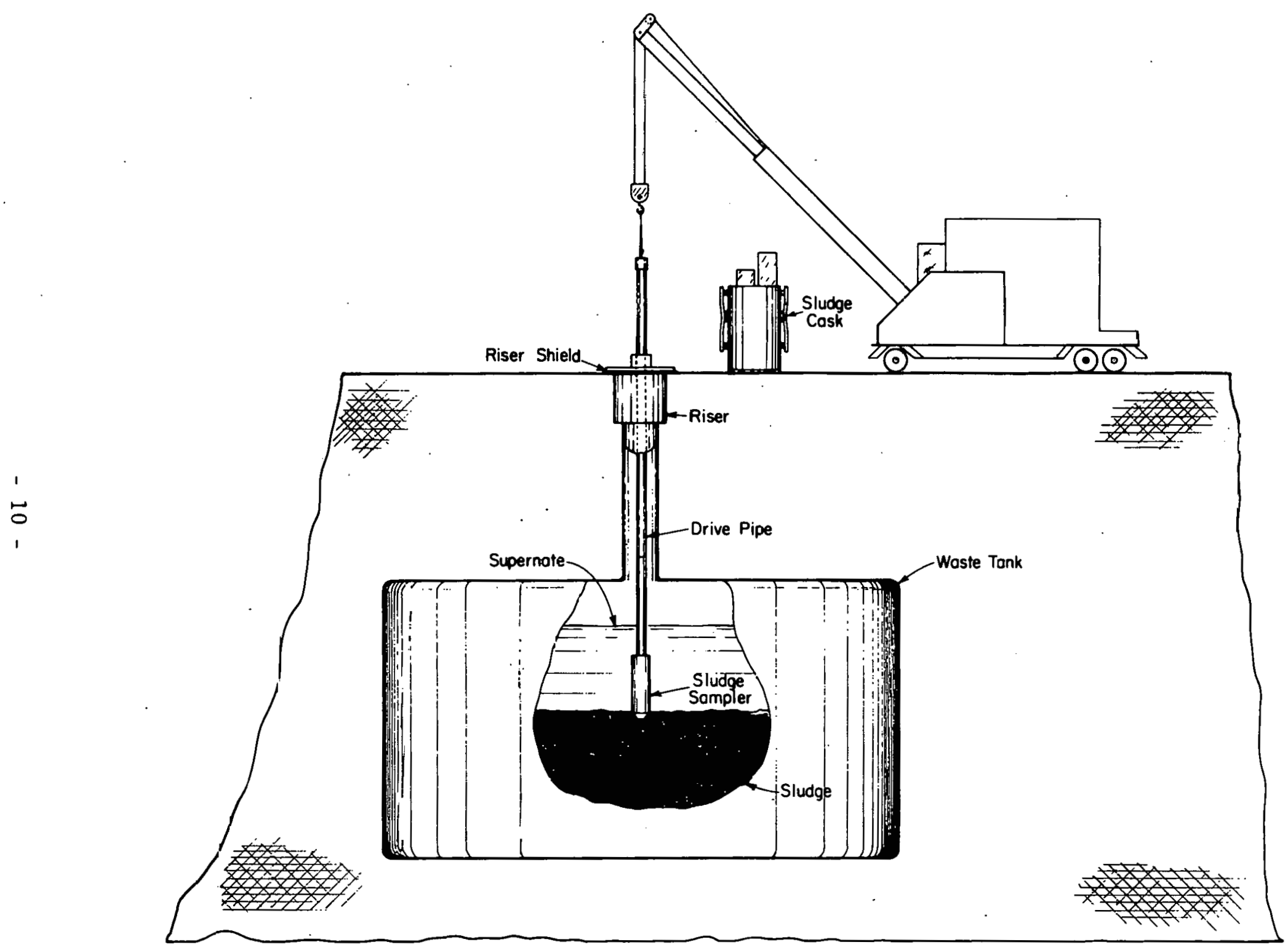

FIGURE 1. Sludge Sampling Equipment 


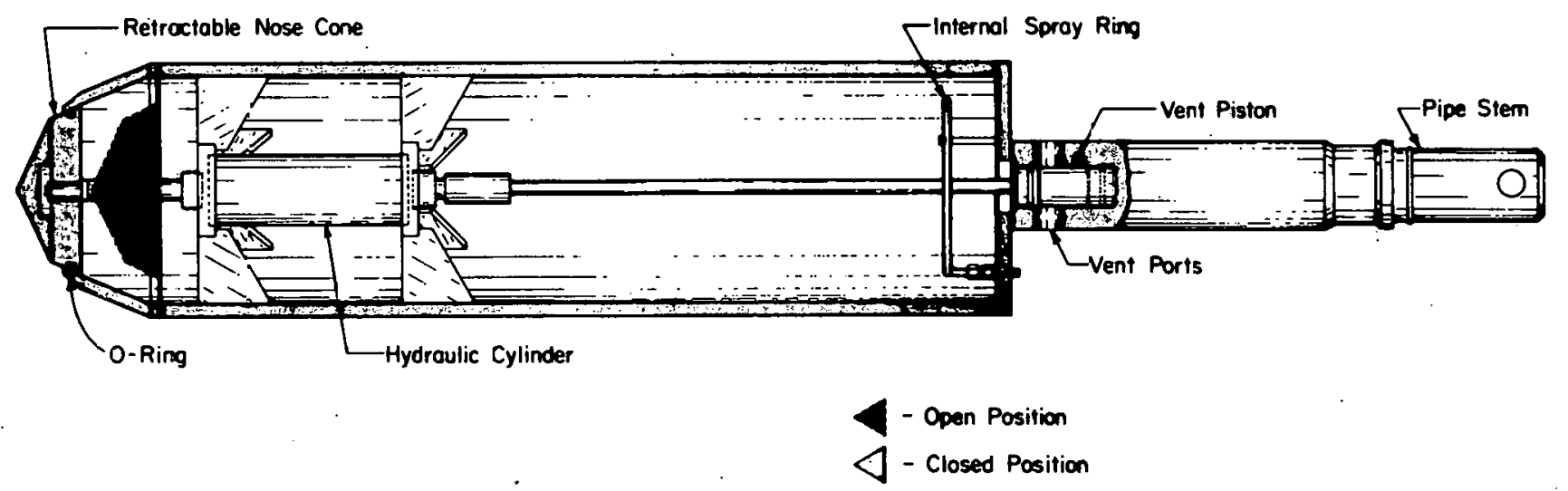

FIGURE 2. Sludge Sampler Cross Section 


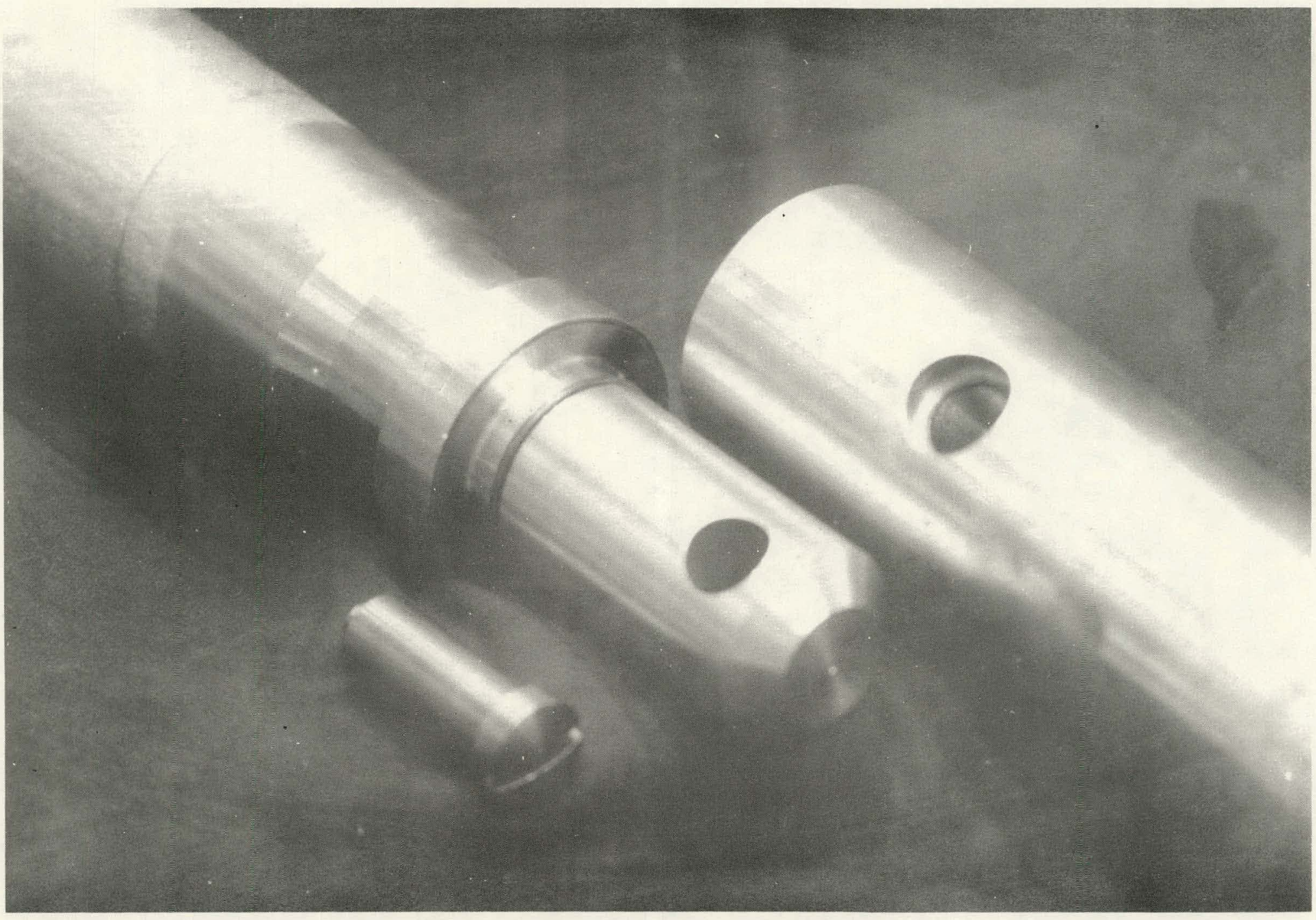

FIGURE 3. Sludge Sampler Drive Pipe Joints and Lockbolt 


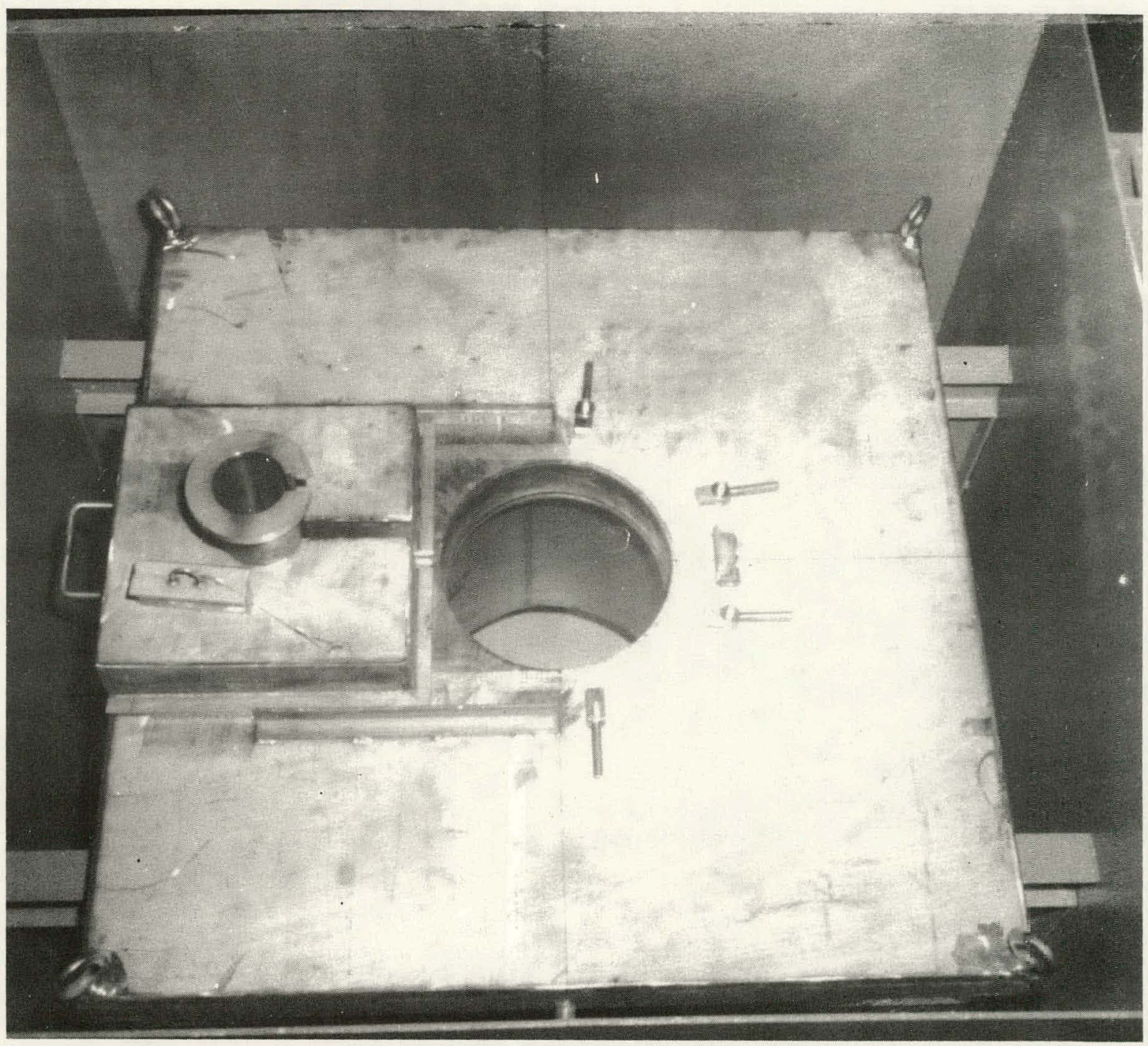

FIGURE 4. Sludge Sampler Cover Shielding in the Open Position 


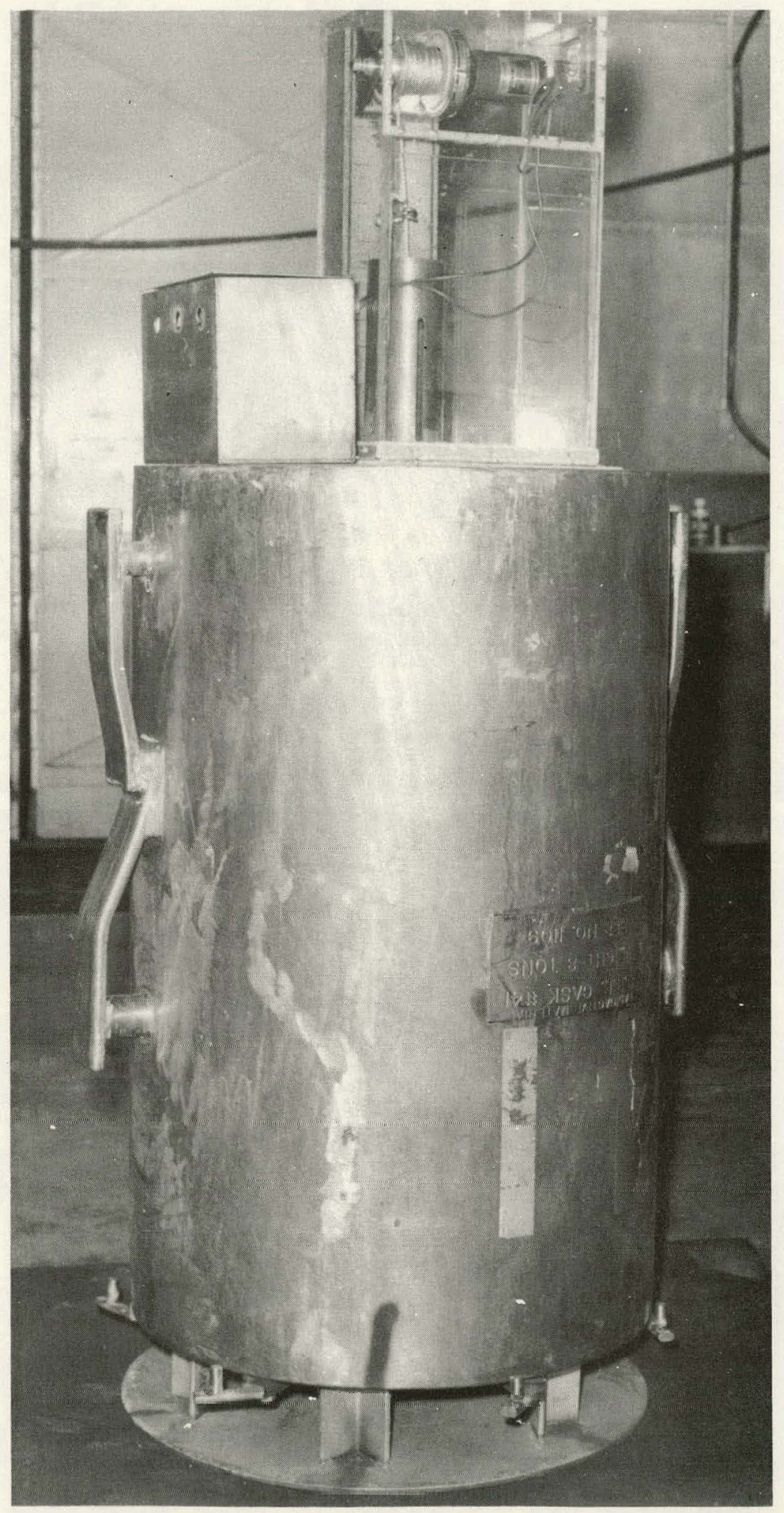

FIGURE 5. Sludge Sampler Transport Cask 


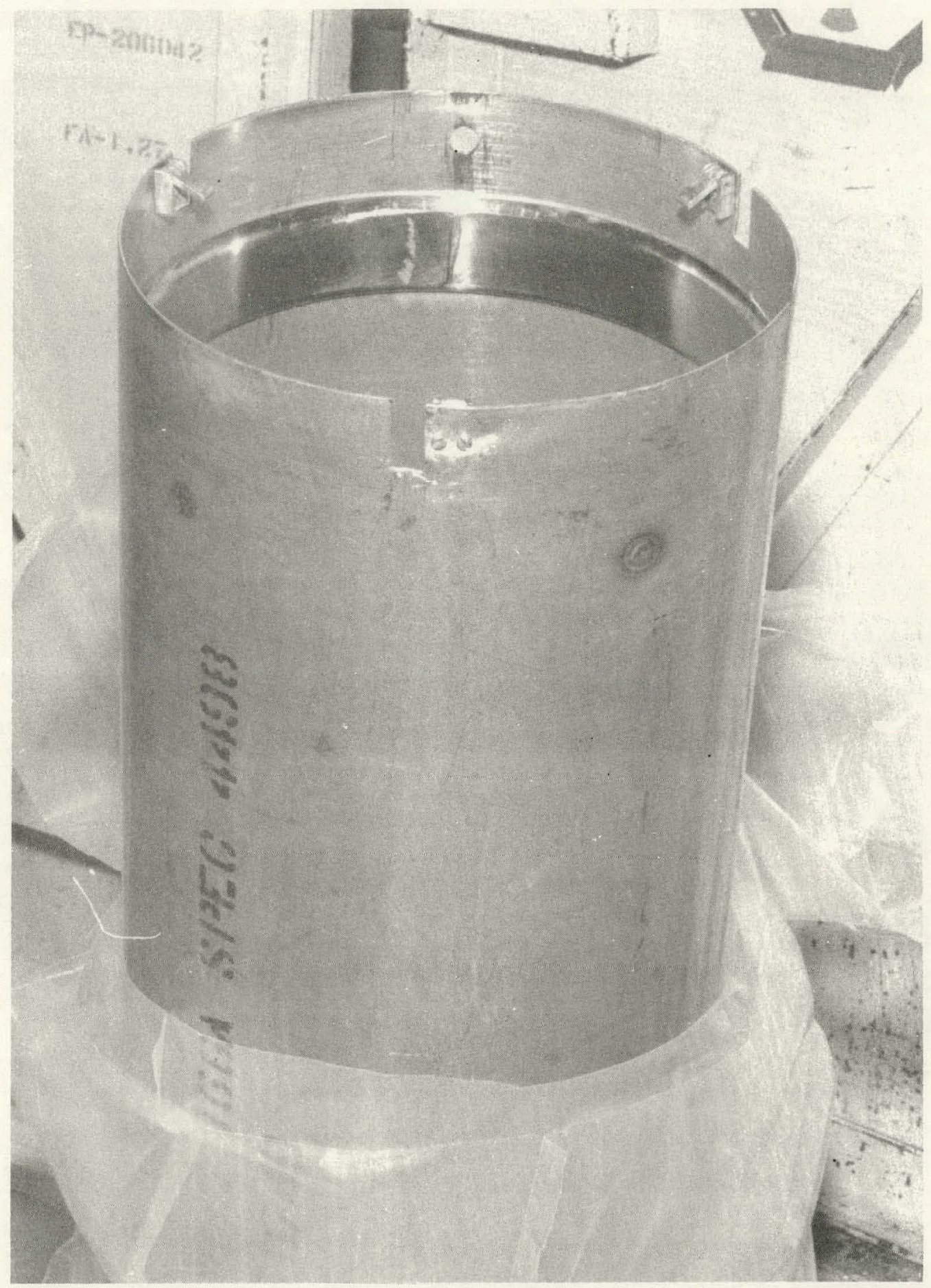

FIGURE 6. Sludge Sampler Secondary Container 


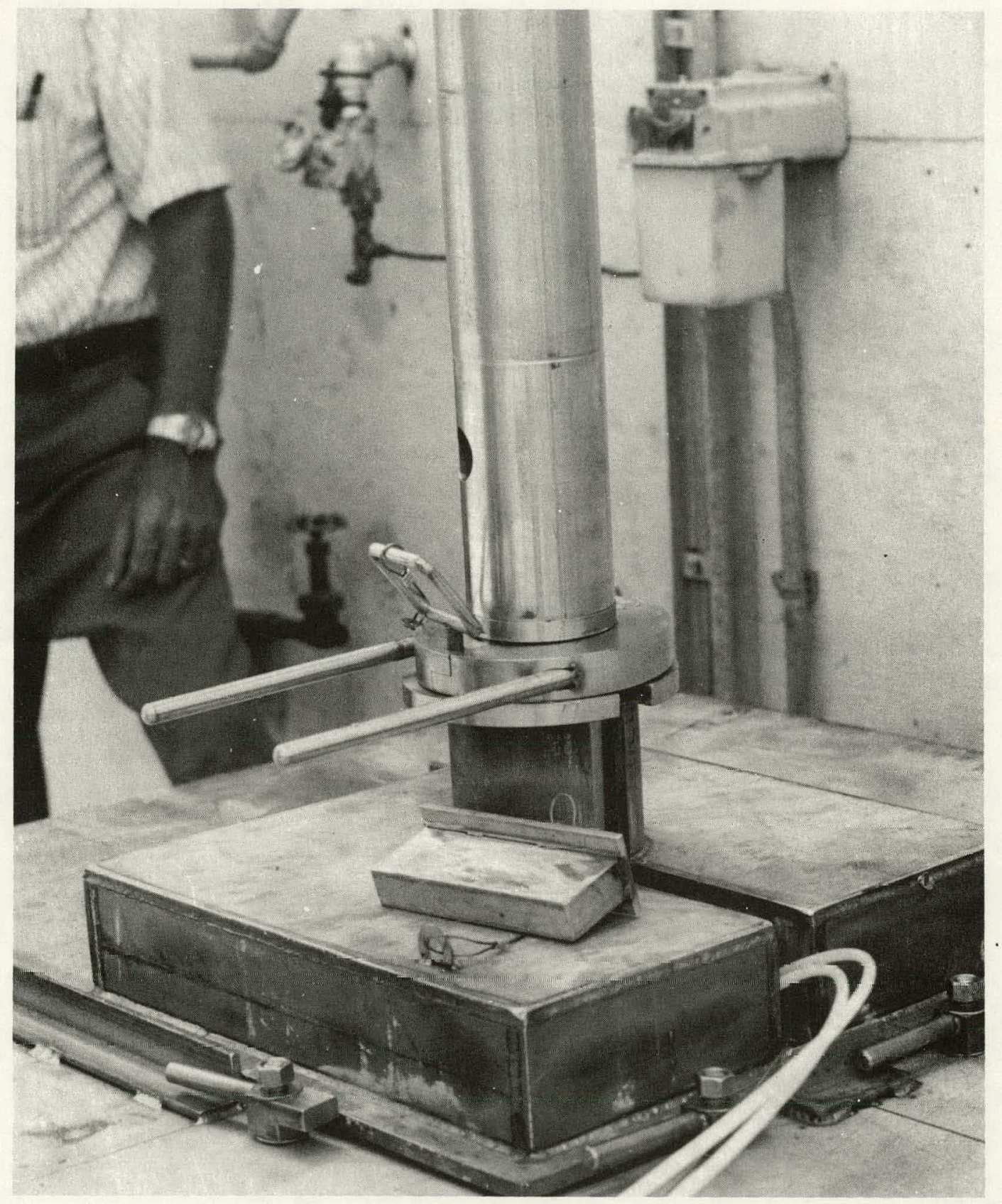

FIGURE 7. Pipe Clamp Installed on Drive Pipe 